\title{
ARCHAEOLOGIST IN THE ARCHIVE. A TURNING POINT IN THE STUDY OF LATE-MEDIEVAL HELMETS IN WESTERN POMERANIA
}

\begin{abstract}
The article discusses three late-medieval head protectors from Western Pomerania, forgotten by Polish scholars after World War II. The first one is the great helm known as the Topfhelm from Dargen, the second, a bascinet with visor from Leszczyn and the last one, the jousting sallet from the collection of Szczecin masons. Knowledge about those helms is highly significant for studies of late-medieval armour in Western Pomerania.
\end{abstract}

Keywords: Western Pomerania, medieval armour, great helm, bascinet, jousting sallet

Received: 15.04.2020 Revised: 29.04.2020 Accepted: 27.07.2020

Citation: Janowski A. 2020. Archaeologist in the Archive. A Turning Point in the Study of Late-medieval Helmets in Western Pomerania. "Fasciculi Archaeologiae Historicae" 33, 167-174, DOI 10.23858/FAH33.2020.011

Elements of armour either in whole or in large fragments belong to unique finds in the archaeology of the Middle Ages. Each more or less complete find is considered a sensation. Western Pomeranian finds are no different in this respect; new finds of this type are few and far between. ${ }^{1}$ The study of primary sources and printed pre-war German accounts shows that such finds did exist; however, they were disregarded by Polish scholarship after 1945. I believe that in this case it might have been important that in the Middle Ages Western Pomerania enjoyed political independence and that it was a separate province; a vast majority of the body of armour studies undertaken after World War II focused on armour from the area of the Kingdom of Poland. In this text I will attempt to recall three pieces of forgotten head defences from Western Pomerania.

\footnotetext{
* Institute of Archaeology and Ethnology, Polish Academy of Sciences, Szczecin; (D) https://orcid.org/0000-0002-3272-3444; a.janowski@iaepan.szczecin.pl

${ }^{1}$ Two finds of pieces of kite shields are an exception - see Dowen et al. 2019.
}

\section{The Great Helm from Dargen}

The first piece of head protection discussed here is a find which must be known to all armour specialists (Fig. 1). It is one of the best preserved and oldest great helms, dating back to the middle-second half of the $13^{\text {th }}$ century. This helm is one of the most precious exhibits in the collection of the Berliner Zeughaus, and is very often referred to in the literature as the Dargen Helm. Until recently the geographical location of this 'Dargen' and the find place of the helm itself have been subject to one of several more or less plausible hypotheses. ${ }^{2}$ Some scholars would point to a vague 'Schlossberg' located close to an equally unidentifiable 'Dargen'3 or Darguń ${ }^{4}$ somewhere in Pomerania. Other attempts at location pointed to

\footnotetext{
${ }^{2}$ Cf. Janowski 2019.

${ }^{3}$ Cf. Blair 1958, 196, Fig. 80; Norman 1964, 12, Fig. 8; Müller and Kunter 1971, 326, Figs. 35-36; Gravett and Turner 1997, 17; Nicolle 1999, 178, no. 451; Pierzak 2005, 42, 272, Fig. 3. The Malbork Castle Museum have a replica of this helmet which was made in late of the $19^{\text {th }}$ century to decorate the St. Anne's Chapel, c.f. Dzikowski 2019.

${ }^{4}$ Chodyński 2003, 35.
} 


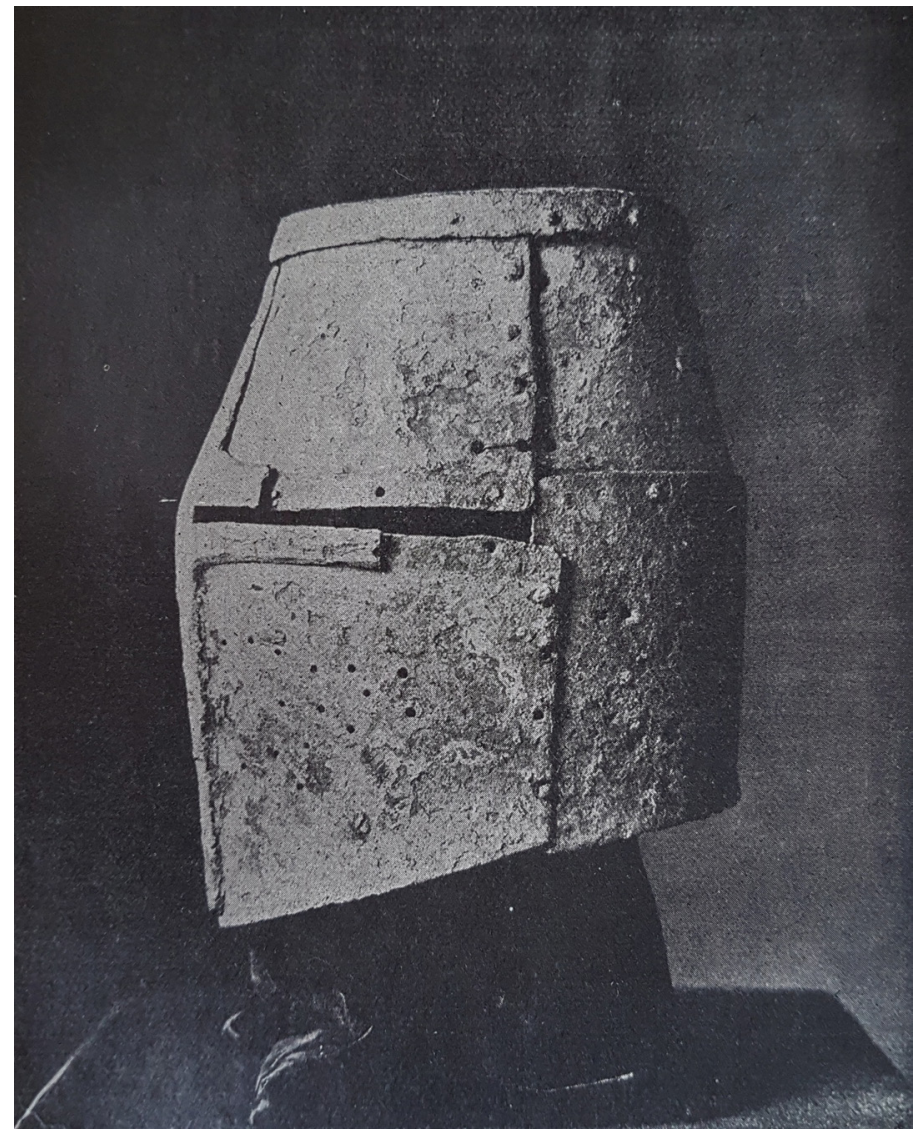

Fig. 1. The Great Helm from Dargen. After Horn 1935, 191.

a Dargen near Szczecin ${ }^{5}$ and a Dargen on the island of Usedom (Uznam). ${ }^{6}$ Paul Post ${ }^{7}$ located the place where the find was made in a Deerberg in Pomerania, but Hugo Schneider, ${ }^{8}$ who quoted the results of this research, turned it into Dargen Castle in Deerberg near Bubach. The whole reasoning seems to be quite farfetched considering the fact that the village of Bubach is located in Rhineland-Palatinate, Western Germany. Nevertheless, this information was duplicated in a few further studies. ${ }^{9}$ No less exotic a location was given by Zdzisław Żygulski Jr. ${ }^{10}$ who wrote about a great helm in the collection of Museum of German History (Museum für Deutsche Geschichte) in Berlin, excavated in Schlossberg Castle (Polkały) in eastern Prussia which dated back to the middle-second half of the $13^{\text {th }}$ century. ${ }^{11}$ In the last decade Sven Lüken ${ }^{12}$ pointed to the location Dargen-Dargin in Koszalin District twice. In the light of information published

\footnotetext{
${ }^{5}$ Kajzer 1976, 112; Wawrzonowska 1976, 37, footnote 27.

${ }^{6}$ Nadolski 1975, 609; Qausigroch 1979, 11; Maciejowski 2000, 281

${ }^{7}$ Post 1929, 26, Fig. 9; Post 1939, 106k.13.

${ }^{8}$ Schneider 1953, 29.

${ }^{9}$ Cf. i.a. Curtis 1978, 24; Žákovský et al. 2012, footnote 5.

${ }^{10}$ Żygulski Jr. 1975, footnote 12.

${ }^{11}$ C.f. Nadolski 1975, 609.

${ }^{12}$ Lüken 2009, 376-377; Lüken 2010, 74.
}

in the West Pomeranian press in the 1930s it is this location that is the correct one, although S. Lüken was inaccurate about some details. ${ }^{13}$

Of particular merit while searching for the true place of origin of the helm are studies by Georg Horn. ${ }^{14}$ In an article published on 12 September 1932 in Unsere Heimat (supplement to Kösliner Zeitung) he described a knight's castle Dargen, Kreis Bublitz. He also mentioned that during some maintenance works on the grounds carried out in the 1860s its owner found a helm. Investigation carried out by Horn revealed that the find arrived in Berlin in July 1869: first at the Royal Art Gallery (Königliche Kunstkammer) and then, in 1876 it was moved to the newly-opened Military Collection in Zeughaus (Waffensammlung des Zeughauses). The inventory note shows Dargen bei Bublitz as the place where the helm was found and the exhibit was given inventory number AD 14311. Currently the inventory number is W1003; both numbers, the previous and the current one, were mentioned by Heinrich Müller and Fritz Kunter ${ }^{15}$ in their description of the helm. Three years after the first publication Georg Horn published another article, this time in Unser Pommerland magazine

\footnotetext{
${ }^{13}$ Cf. Janowski 2019.

${ }^{14}$ Horn 1932.

${ }^{15}$ Müller and Kunter 1971, 326.
} 


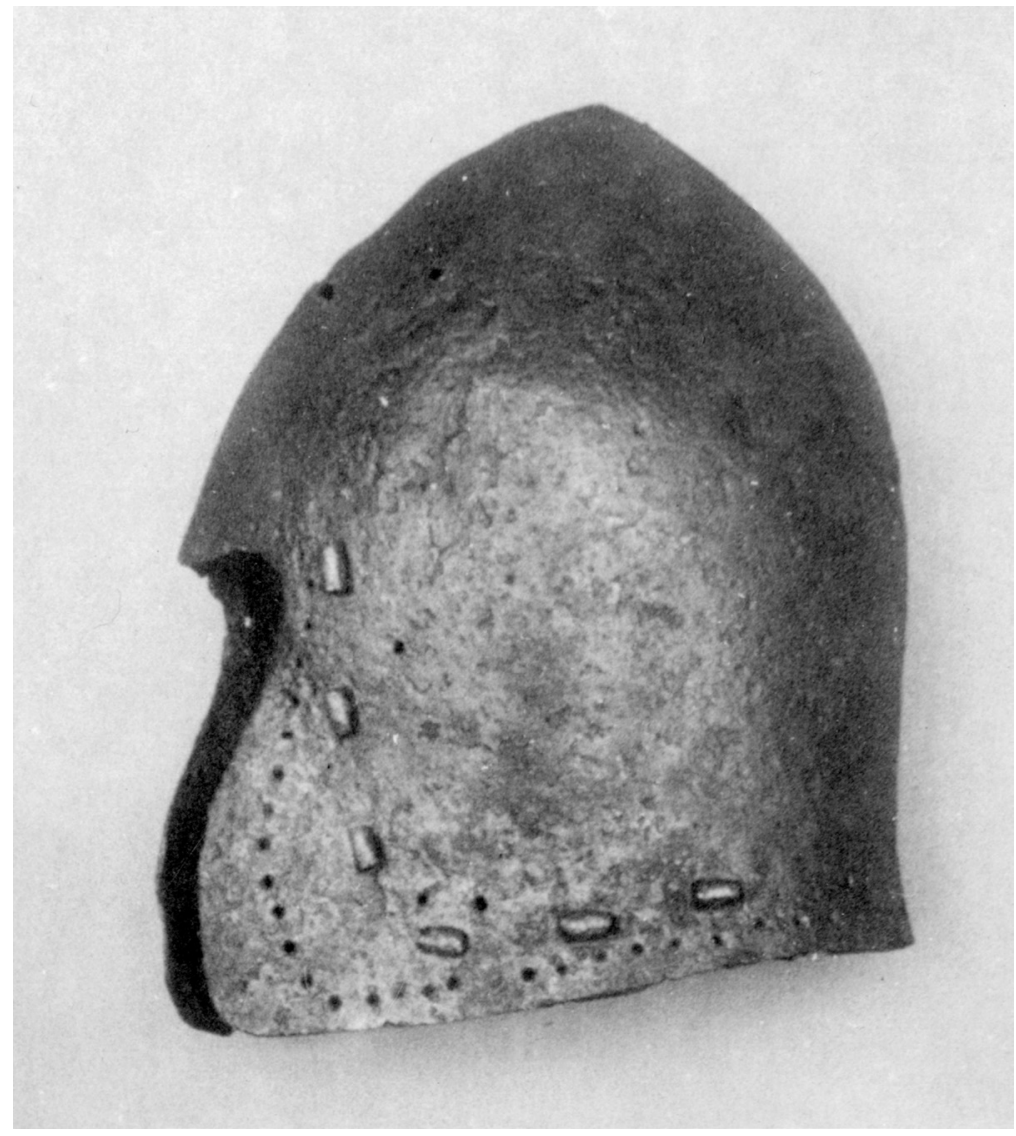

Fig. 2. Bascinet from Leszczyn. After Kunkel 1931, Tab. 108.

under a very telling title: "Der Topfhelm aus Dargen". To some extent he restated earlier information, but he also inserted a photograph of the helm which leaves no doubt that it is the piece of head protection of interest to us. ${ }^{16}$ The place Dargen, Kreis Bublitz, which is mentioned in the articles quoted above is now known as Dargin, in the Bobolice District of the West Pomeranian voivodeship. The name Bubach is most probably a distortion of Bublitz, that is Bobolice. Based on data referred to in some other article published in the 1930s is can be stated quite unambiguously that the place where the helm was discovered is the archaeological site described later as late medieval motte fortification - Dargiń, archaeological site no. $1 .{ }^{17}$

\section{Bascinet from Leszczyn}

The helm from Leszczyn is one more example of a forgotten piece of head protection. A short note published in the 1870s in Baltische Studien indicates that Earl von Manteuffel donated a thirty-centimetre-high helmet via a grammar school teacher, Herr Meier from Kołobrzeg, to the collection of the Society of History and Antiquities of Pomerania in Szczecin (Gesellschaft

\footnotetext{
${ }^{16}$ Horn 1935.

${ }^{17}$ This site was excavated in 1966, but without success. Cf. Janowski 2019, therein older literature.
}

für Pommersche Geschichte und Altertumskunde) (Fig. 2). Together with the helm, also a bridle, horseshoes, two spurs eighteen centimetres long, and two spearheads: eighteen and thirty-centimetres long were donated. All the weaponry supposedly came from the ruins of the castle in Leszczyn near Rymań (Lestin bei Romahn) and were buried in the ground. ${ }^{18}$ The collection was given inventory number 1455. Supposedly, after 21 December 1927 the helm was included in the collection of the newly-established Provincial Museum of Pomeranian Antiquities (Provinzialmuseum Pommerscher Altertümer), which was changed into the Museum of Pomerania (Pommersches Landesmuseum in Stettin) in Szczecin in 1934; anyway, it was a part of a permanent exhibition of the museum, shown in pictures of showcases kept in the Photo Archive of the National Museum in Szczecin.

It was well before the outbreak of World War II that the picture of the side of the helm appeared in an article by Otto Kunkel, in which the helm was described as a bascinet (Germ. Kesselhaube); (Fig. 2). ${ }^{19}$ The helm seen in the plate is cone-shaped. The front bottom edge of the helm is slightly lower whereas the side edges

\footnotetext{
${ }^{18}$ BS 1879,142 . This site was examined only by archaeological surface methods in 2019.

${ }^{19}$ Kunkel 1931, 104, Tab. 108.
} 


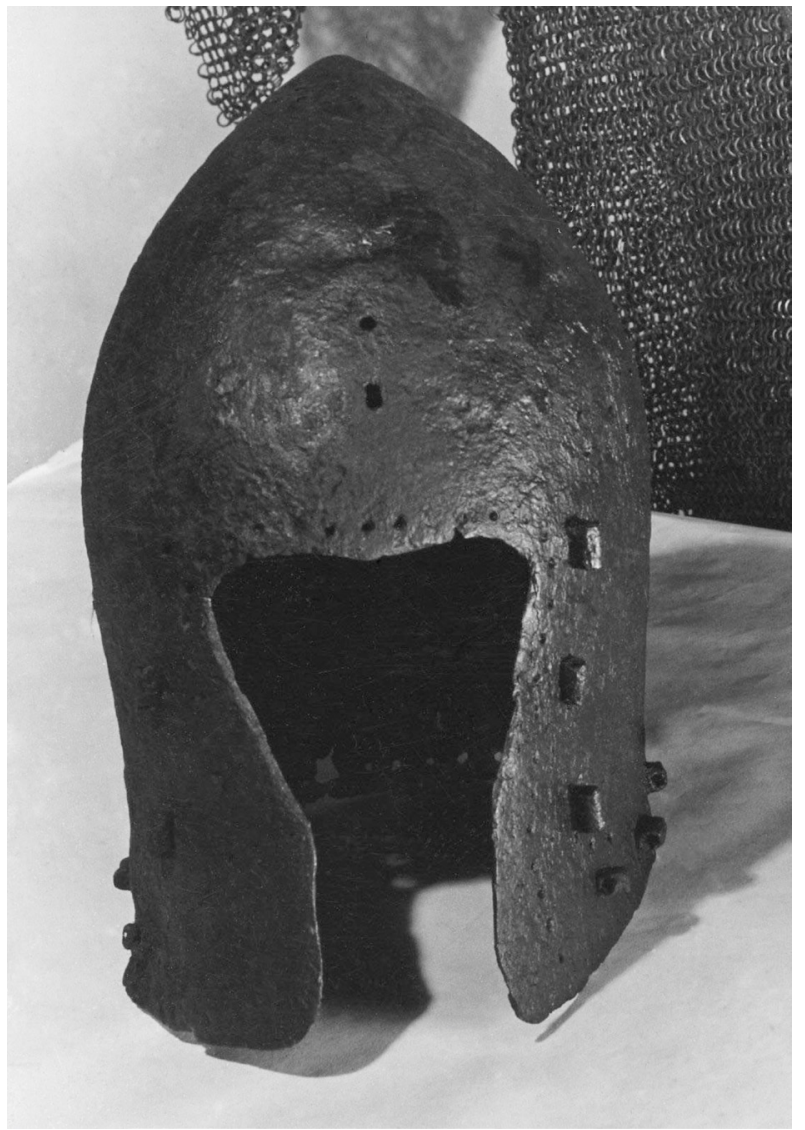

Fig. 3. Bascinet from Leszczyn. Photo from the Archiwum Fotograficzne MNS/Photo Archive National Museum in Szczecin.

around the face were drawn forward thus allowing the helm to protect the cheeks. Running along the lower and the front edge small holes can be seen which were used to attach a lining or padding. Above the holes, running parallel to them there are six pipe hooks or studs which were used to attach the aventail. The picture in O. Kunkel's publication does not give any insight into a possible visor nor the way it was attached to the bascinet. Such an insight, however, is given by a picture preserved in the already mentioned Photo Archive of the National Museum in Szczecin where the bascinet is presented en face (Fig. 3). In this shot two holes can be seen, a square one and, slightly above it, a circular one; they were used to attach the visor. Also of interest is the bottom of the forehead part, which is neither straight nor profiled so the upper part of the skull of the bascinet protecting the forehead is in a way heart-shaped. Such a construction feature allows us to classify the helm from Leszczyn as an early bascinet with a visor. It is assumed that bascinets with a movable visor on a central hook appeared between 1340 and 1370, and in the Kingdom of Poland around the middle of the $14^{\text {th }}$ century. ${ }^{20}$ The helm from Siedlątków dated to around 1370 and a few

${ }^{20}$ Cf. Głosek 2007, therein older literature. further relics from West European collections whose chronology is quite similar (1350-1380) are a perfect analogy to the artefact discussed here..$^{21}$

Nothing is known about what happened to the helm after World War II. It is not in the collection of the National Museum in Szczecin, although other artefacts donated by Count von Manteuffel survived in the archaeological collection of this institution. ${ }^{22}$ They include a spur, spearhead, bridle and horseshoe. Some knowledge of the artefacts allows concluding that the count's collection did not date back to single period in history. The bascinet probably dates back to $1350-1380$ while the spur with clearly worked out heel bands and a long neck, which has survived down to our times, is characteristic of the second half of the $15^{\text {th }}$ century, i.e. it is one hundred years younger.

${ }^{21}$ Cf. i.a. Nadolski 1969, 9-10; Müller and Kunter 1971, 326327, cat. no. 4-5; Scalini 1996, cat. no. 24.

${ }^{22}$ The helmet was probably in another, that is, a non-archaeological collection. The reason for such conclusions may be the fact that the helm with visor (Helm mit Visier) was mentioned on the evacuation list of the Museum in Szczecin in 1945, described in general as an element of the collection (with a $\mathrm{Z}$ sign). It can be assumed that this is the helmet. I would like to thank Krzysztof Kowalski from the Archaeology Department of the MNS for this information. 


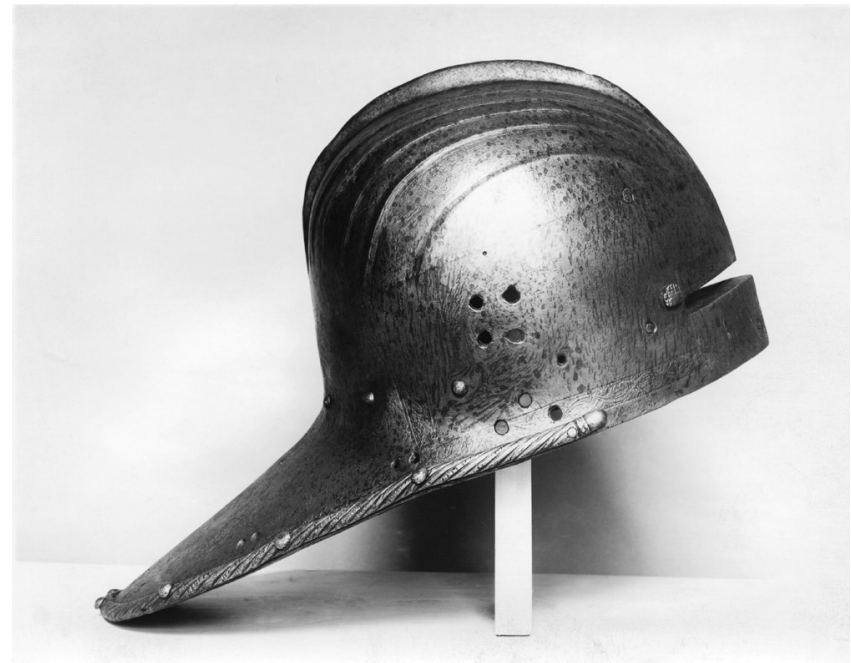

Fig. 4. Jousting sallet, before World War II in the collection of the Provincial Museum of Pomeranian Antiquities in Szczecin. After Closs 1932-1934, Fig. 1.

\section{Jousting Sallet}

The most enigmatic is the third piece of head protection discussed here. In this case there can be no certainty whether it came from Western Pomerania. However, before World War II it was a part of the collection of the Provincial Museum of Pomeranian Antiquities (Provinzialmuseum Pommerscher Altertümer), which can be seen in pictures and read about in a short text published by Adolf Closs in Zeitschrift für Waffen- und Kostümkunde (Fig. 4). ${ }^{23}$ According to anote, this helm was purchased between 1828 and 1845 by the masonic lodge Under Three Compasses (Zur den Drei Zirkeln). ${ }^{24}$ The artefact is a tournament helm (Rennhut), a sallet which was used during jousting. The helm weighed 6.25 pounds (about $2.9 \mathrm{~kg}$ ) and was made from a single sheet of steel. The skull is cylindrical; the rear of the helmet was drawn out into a long tail curved at an angle of almost $90 \%$. The top of the skull is decorated with a comb and fluting: five grooves running on each side. The face part is relatively short with a narrow slit to provide vision. At the side of the slit there are large rivets to attach additional forehead protection and decorative elements such as horns, feathers, wings or a mane which fell off when the knight was struck with a lance. The protection was additionally attached (spring mechanism?) to the central comb - there is a clearly visible hole for the mechanism. In the lower part of the skull there is a series of studs to fasten the padding. According to A. Closs, the four holes by the ear were used to fasten the helm on the head. The outer part of the helm was decorated with a ferrule in the

\footnotetext{
${ }^{23}$ Closs 1932-1934.

${ }^{24}$ It was the oldest lodge in Szczecin founded in 1762 - see Lincke 1862.
}

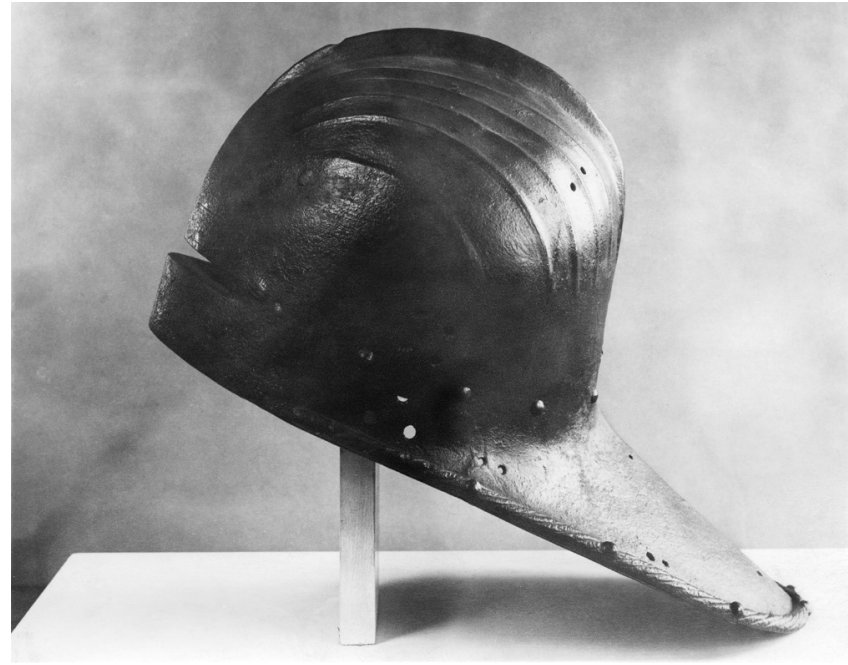

Fig. 5. Jousting sallet. Photo from the Archiwum Fotograficzne MNS/Photo Archive National Museum in Szczecin.

shape of a twisted rope. The skull was also decorated with an etched cherub ${ }^{25}$ and parallel to the lower edge of the helm there is a plant and geometric design. There are no markings of the manufacturers, which makes it difficult to point to the place where it was made. According to Adolf Closs the helm may date back to the 1510s. In the Photo Archive of the National Museum in Szczecin there are preserved photos of this sallet shown from different sides (Figs. 5 and 6), described as Rennhut (Turnierhelm) mit geätzlem Ornament, Augsburg um 1520-30. II d7.561. The closest analogy both in terms of construction (one sheet of steel), shape (semi-circular tail) as well as decoration (fluting, decorations on the edge of the tail) is a piece in the Tower of London's collection, defined as manufactured in Germany and also dated to 1510-1520. ${ }^{26}$ The helm of such a structure, fitted with decorative horns and an additional forehead plate can also be seen on the head of a West Pomeranian tournament champion, Wolf(gang) von Borcke (Fig. 7) during a jousting tournament when participants wielded lances with sharp tips in a Copenhagen tournament which was held between 1509 and 1511. Similar headgear protected also the heads of other participants in the joust. ${ }^{27} \mathrm{~A}$ bit earlier (1490-1510) is the timeline of two artefacts from the arsenal of Emperor Maximilian I (1459-1519) in Vienna, which were made by a family of armourers, the Helmschmids from Augsburg. ${ }^{28}$ Nothing is known about what happened to

\footnotetext{
${ }^{25}$ It cannot be excluded that the cherub, an important symbol of freemasonry, was the reason the Masons became interested in the artefact.

${ }^{26}$ Cf. Dufty 1968, P1. LXXIX:e.

${ }^{27}$ See Turnierbuch 1520-1532; Brzustowicz 2006.

${ }^{28}$ See Thomas and Gamber 1976, 169-170, 173-174,
} 


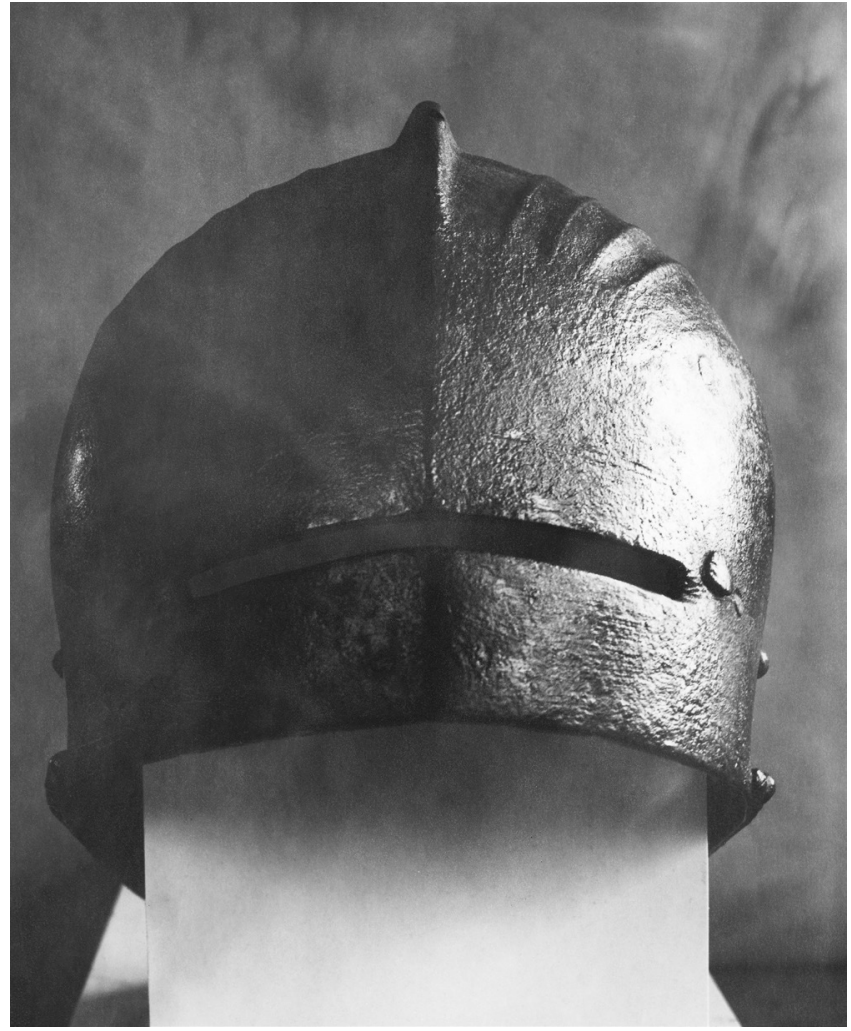

Fig. 6. Jousting sallet - front view. Photo from the Archiwum Fotograficzne MNS/Photo Archive National Museum in Szczecin.

the Rennhut after World War II. The helmet marked with the number II d 7561 (similarly to the helmet in question) described as Eiserner Sturmhelm was mentioned on the evacuation list in January 1945, then in box number 12 it was transported to Hintersee (today Germany) $35 \mathrm{~km}$ north-west of Szczecin. Artefacts from this transport did not return to the Museum in Szczecin.

The article discusses three pieces of West Pomeranian head protection, which have been forgotten by Polish scholars. Let it be known how important the knowledge of their existence is by recalling the fact that

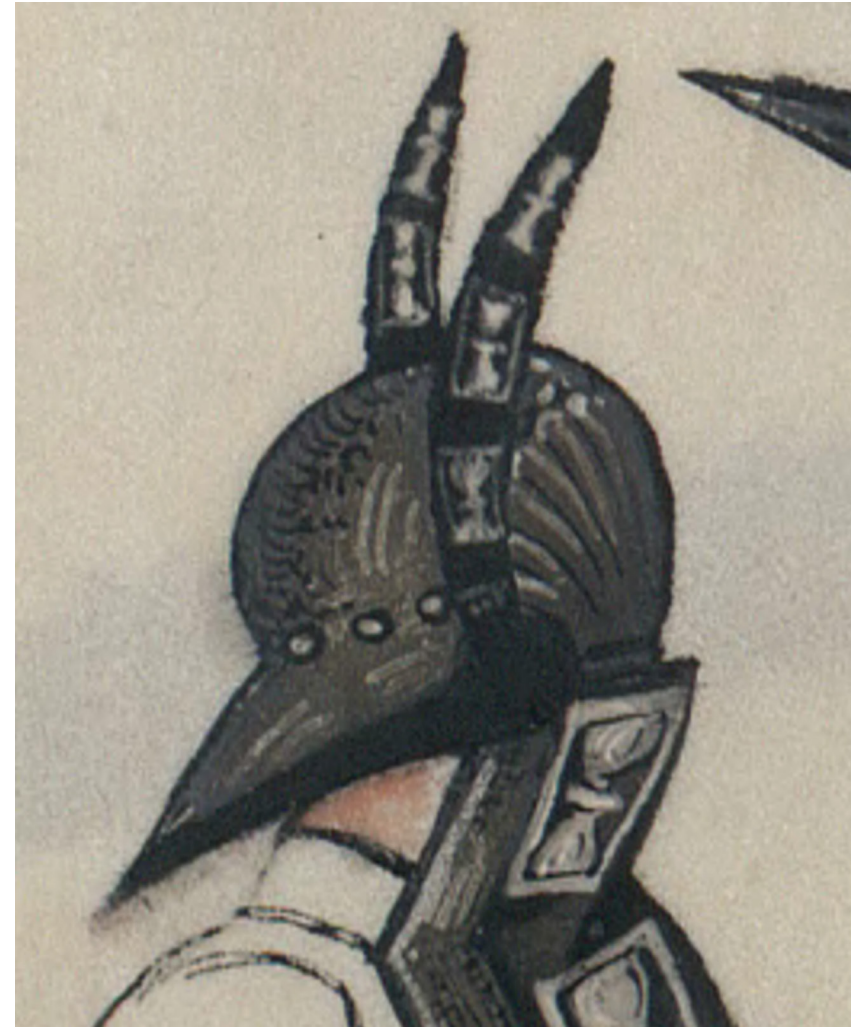

Fig. 7. Jousting Sallet of Wolf(gang) von Borcke during tournament in Copenhagen (1509-1511?) After Turnierbuch 1520-1532, Pl. 130.

only 20 to 30 years ago Andrzej Nowakowski, ${ }^{29}$ while presenting studies on late-medieval helms wrote about no more than four artefacts from the area of the Polish Kingdom and a further five from outside its territory Since that time the collection has expanded,,$^{30}$ but it is still so limited that each new piece is virtually priceless. Therefore, restoring knowledge about the place of excavation of the Topfhelm from Dargen (Dargiń), the bascinet with visor from the Leszczyn as well as information about a jousting sallet from the collection of the Szczecin freemasons is of vital significance for the studies on late-medieval armour in Western Pomerania.

\section{Sources}

Turnierbuch 1520-1532 - Turnierbuch des Herzog Heinrich des Mittlern von Braunschweig-Lüneburg (1510-1532). https://jbc.bj.uj.edu.pl/dlibra/publication/177800/edition/169160?language=en. Available on-line 06.11.2019.

\section{Bibliography}

Blair C. 1958. European Armour circa 1066 to circa 1700. London.

Figs. 80-81

\footnotetext{
${ }^{29}$ Nowakowski 1990, 40; Nowakowski 1998, 70.

${ }^{30}$ See i.a. Głosek and Muzolf 2002; Michalak et al. 2008; Ławrynowicz 2009.
} 
Brzustowicz B. W. 2006. Wolf von Borcke. Zapomniany pomorski czempion turniejowy? In: K. Kozłowski, W. Wróblewski (eds.), Pomorze militarne XII-XXI w. 2. Szczecin, 201-211.

BS 1879 - Beilage. Erwerbungen des antiquarischen Museums von Ende August bis Ende November 1878. "Baltische Studien" 29, 139-142.

Chodyński A. R. 2003. Broń i barwa w czasach krzyżackich od XIII do połowy XVI wieku. Malbork.

Closs A. 1932-1934. Ein Rennhut im Provinzialmuseum Pommerscher Altertümer. "Zeitschrift für Historische Waffen- und Kostümkunde" N.F. 4, 88-90.

Curtis H. M. 1978. 2,500 Years of European Helmets: 800 B.C.-1700 A.D. North Hollywood.

Dowen K., Marek L., Słowiński S., Uciechowska-Gawron A., Myśków E. 2019. Two Twelfth-Century Kite Shields from Szczecin, Poland. “Arms \& Armour" 16(2), 121-148.

Dufty A. R. 1968. European Armour in the Tower of London. London.

Dzikowski A. 2019. Hetm garnczkowy w zbiorach militariów Muzeum Zamkowego w Malborku. "Studia Zamkowe" 6, 81-94.

Eggers H. J., Bollnow H. 1935. Vor- und Frühgeschichte des Kreises Bublitz. "Unser Pommerland" 20(3-4), 100-116.

Głosek M. 2007. Przyczynek do genezy hełmów typu przyłbica. In: M. Głosek, J. Maik (eds.), Od pradziejów do wspótczesności. Archeologiczne wędrówki. Acta Archaeologica Lodziensia 53. Łódź, 14-16.

Głosek M., Muzolf B. 2002. Dwa fragmenty hetmów średniowiecznych znalezione na zamku w Smoleniu, pow. Olkusz. "Kwartalnik Historii Kultury Materialnej" 50(1), 35-47.

Gravett Ch., Turner G. 1997. German Medieval Armies 1000-1300. Osprey Military. Men at Arms Series 310. Oxford.

Horn G. 1932. Der Wall in Dargen, Kreis Bublitz. "Unsere Heimat. Beilage zur Kösliner Zeitung” 1932(14), 3-4.

Horn G. 1935. Der Topfhelm aus Dargen. "Unser Pommerland 20(3-4), 191-192.

Janowski A. 2019. Gdzie leży Dargen? Rozwiazanie stuletniej zagadki. "Acta Militaria Mediaevalia" 15, 129-135.

Kajzer L. 1976. Uzbrojenie i ubiór rycerski w średniowiecznej Małopolsce w świetle źródet ikonograficznych. Wrocław, Warszawa, Kraków, Gdańsk.

Kunkel O. 1931. Pommersche Urgeschichte in Bildern. Stettin.

Lincke A. G. C. 1862. Geschichte der St. Johannis-Loge zu den drei Zirkeln früher la parfaite union im Oriente Stettin. Stettin.

Lüken S. 2009. Topfhelm. In: M. Puhle, N. Lammert (eds.), Aufbruch in die Gotik. Der Magdeburger Dom und die späte Stauferzeit 2. Katalog. Magdeburg, Mainz, 376-377.

Lüken S. 2010. Topfhelm. In: R. Atzbach, S. Lüken, H. Ottomeyer (eds.), Burg und Herrschaft. Berlin, Dresden, 74.

Ławrynowicz O. 2009. Nowo odkryty kapalin z Włocławka na tle porównawczym. "Acta Militaria Mediaevalia" 5, 175-195.

Maciejowski M. 2000. Wizerunek hetmu garnczkowego na pieczęciach rycerstwa zachodniopomorskiego w pierwszej połowie XIV w. w zbiorach Muzeum Narodowego w Szczecinie. "Materiały Zachodniopomorskie" 46, 279-286.

Michalak A., Kwaśniewicz W., Wawrzyniak P. 2008. Salada typu niemieckiego ze zbiorów Lubuskiego Muzeum Wojskowego w Drzonowie koło Zielonej Góry. "Acta Militaria Mediaevalia” 4, 199-221.

Müller H., Kunter F. 1971. Europäische Helme aus der Sammlung des Museums für Deutsche Geschichte. Berlin.

Nadolski A. 1969. Hetm i fragmenty zbroi z XIV wieku znalezione w Siedlatkowie nad Warta. "Studia do Dziejów Dawnego Uzbrojenia i Ubioru Wojskowego" 4, 5-23.

Nadolski A. 1975. Mediewalia w książce Zdzisława Żygulskiego (jun.) 'Broń w dawnej Polsce'. "Kwartalnik Historii Kultury Materialnej” 23(4), 605-615.

Nicolle D. 1999. Arms and Armour of the Crusading Era, 1050-1350 1. Western Europe and the Crusader States. London.

Norman V. 1964. Arms and Armour. London.

Nowakowski A. 1990. Uzbrojenie ochronne. In: A. Nadolski (ed.), Uzbrojenie w Polsce średniowiecznej 13501450. Łódź, 31-110.

Nowakowski A. 1998. Uzbrojenie ochronne. In: A. Nowakowski (ed.), Uzbrojenie w Polsce średniowiecznej 14501500. Toruń, 73-105.

Pierzak J. 2005. Średniowieczne hetmy garnczkowe na ziemiach polskich na tle zachodnioeuropejskim. Rocznik Muzeum Górnośląskiego w Bytomiu. Archeologia 16. Bytom.

Post P. 1929. Das Zeughaus: die Waffensammlung. Kriegs-, Turnier- und Jagdwaffen vom frühen Mittelalter bis zum Dreißigjährigen Krieg. Ein Handbuch der Waffenkunde. Berlin.

Post P. 1939. Das Kostüm und die ritterliche Kriegstracht im deutschen Mittelalter von 1000-1500. Berlin.

Qausigroch G. 1979. Der Topfhelm von Dargen. "Waffen- und Kostümkunde" 21, 11-24. 
Scalini M. 1996. L'Armeria Trapp di Castel Coira. Die Churburger Küstkammer. The Armoury of the Castle of Churburg. Udine.

Schneider H. 1953. Die beiden Topfhelme von Madeln: die Entwicklungsgeschichte des Topfhelms. "Zeitschrift für schweizerische Archäologie und Kunstgeschichte" 14(1), 24-46.

Thomas B., Gamber O. 1976. Katalog der Leibrüstkammer. I. Teil der Zeitraum von 500 bis 1530. Wien.

Wawrzonowska Z. 1976. Uzbrojenie i ubiór rycerski Piastów ślaskich od XII do XIV wieku. Łódź.

Žákovský P., Hošek J., Cisár W. 2012. A Unique Finding of a Great Helm from the Dalečín Castle in Moravia. "Acta Militaria Mediaevalia" 8, 91-125.

Żygulski Z. Jr. 1975. Broń w dawnej Polsce na tle uzbrojenia Europy i Bliskiego Wschodu. Warszawa. 